\title{
Nutrients Available and Stable Carbon from Archaeological Black Earth
}

\author{
Antônio Roberto de Oliveira Meireles 1,2, Vanda Porpino Lemos²*, \\ Orivan Maria Marques Teixeira ${ }^{3}$, Kelly das Graças Fernandes Dantas ${ }^{2}$, \\ Marcelly Christian Galvão Rodrigues Machado², Milena Carvalho de Moraes ${ }^{4}$ \\ ${ }^{1}$ School Tenente Rego Barros, Belém, Brazil \\ ${ }^{2}$ College of Chemistry, Institute of Exact and Natural Sciences, Federal University of Pará, Belém, Brazil \\ ${ }^{3}$ Soil and Plant Laboratory, Brazilian Agricultural Research Corporation, Belém, Brazil \\ ${ }^{4}$ Coordination of Earth Sciences and Ecology, Emílio Goeldi Museum of Pará, Belém, Brazil \\ Email: *vplemos@ufpa.br
}

How to cite this paper: Oliveira, A.R.M. Lemos, V.P., Teixeira, O.M.M., Dantas, K.G.F., Machado, M.C.G.R. and Moraes, M.C. (2021) Nutrients Available and Stable Carbon from Archaeological Black Earth. Journal of Environmental Protection, 12 , 873-886.

https://doi.org/10.4236/jep.2021.1211051

Received: October 4, 2021

Accepted: November 15, 2021

Published: November 18, 2021

Copyright (c) 2021 by author(s) and Scientific Research Publishing Inc. This work is licensed under the Creative Commons Attribution International License (CC BY 4.0).

http://creativecommons.org/licenses/by/4.0/

\begin{abstract}
The present study aims affinity between available concentrations of phosphorus, micronutrients $(\mathrm{Cu}, \mathrm{Zn}$ and $\mathrm{Mn})$ and stable carbon (SC) in archaeological black earth (ABE) from area "Ilha de Terra"/Caxiuanã-Pará. The relevance of this study refers especially to the determination of carbon concentrations (total, oxidable and semi-labile carbon) directly associated with those of pyrogenic carbon, common in $\mathrm{ABE}$, which should add their contributions to the understanding of soil organic matter recalcitrance. Chemical properties such as CEC and base saturation were determined for ABE and subjacent Latossoil. The available concentrations of nutrients were performed from sequential extraction F1 to F5 phases. Phosphorus was obtained by spectrophotometric method and micronutrients by MP-AES. TOC was determined by the combustion method; stable carbon was obtained from thermoxidation method CTO-375. The following results were obtained from ABE: CEC effective $=21$ to $28\left(\mathrm{cmolc} \cdot \mathrm{L}^{-1}\right)$; base saturation $=58 \%$ to $69 \%$; Carbon concentrations (\%): TOC $=2.95$ to 3.94 ; $\mathrm{SC}=0.25$ to 0.88 ; semi-labile carbon $=1.75$ to 3.63 ; oxidable $=2.11$ to 3.65 ; inorganic carbon 0.01 to $0.38 ; \mathrm{P}_{2} \mathrm{O}_{5}$ concentrations (mg. $\mathrm{kg}^{-1}$ ) in the $\mathrm{ABE}$ phases $\mathrm{F} 3$ (Fe-Mn oxides, $\mathrm{F} 4$ (organic ) and $\mathrm{F} 5$ (residual)) in the following order: 35 to $65 ; 200$ to $400 ; 140$ to 230 . It was concluded that the chemical properties in ABE from Ilha de Terra site fall within the range of fertile and the high concentrations of phosphorus are biogenic origin. Phases F3 and F4 are those considered nutrient stocks from ABE studied area.
\end{abstract}

\section{Keywords}

Pyrogenic Carbon, Oxidable Carbon, Phosphorus, Micronutrients, Soil 
Organic Matter

\section{Introduction}

Fertility in soils known as archaeological black earth $(\mathrm{ABE})$ is generally superior to other classes of soils in the Amazon and nutrients losses from leaching are low, thus reflecting the high stability of organic matter in ABE [1] [2] [3] in relation to adjacent soils and other types of soils and this characteristic fits among the main lines of research in the area of Soil Science with the application of methods of chemical characterization of organic matter of tpas, aiming especially the determination of properties indicating the high stability of organic matter in ABE [2] [3] [4] [5].

The ABE occurred as dark spots, distributed in several places in the central Amazon. It was identified by, being most well-known in places near the city of Manaus [6], such as: 1) occurrences in the district of Iranduba, collected in seven places under tertiary and quaternary sediments [7];2) in occurrences, distributed in different districts as anthropogenic soils over forest and cultivation [8]; 3) occurrences in the district of Manacapuru at two sites, Jiquitaia and Laranjal [9] contrasting environments. The first under Holocene sediments with clayey texture, and the second under mature sediments from Alter do Chão Formation. In the occurrences of $\mathrm{ABE}$ referred to above, the concentrations of total organic carbon, phosphorus, copper, iron, manganese and zinc were evaluated [10].

In the region of Caxiuanã, located in the western portion of the state of Pará, between Portel and Melgaço districts studies were carried out on the geology, archeology and geochemistry of the region, with several occurrences of ABE being recorded, such as those of the Manduquinha sites, Ponta Alegre, Mina II and Ilha de Terra, these occurrences being recorded under Latosols, correlated with the Alter do Chão Formation [11].

The studies carried out on the Ilha de Terra site, involving: the chemical characterization in terms of the distribution of phosphorus, $\mathrm{Ca}, \mathrm{Mg}$ and organic matter for the purpose of reconstituting past human behavior in a Tpa area of this site; from the $\mathrm{O} / \mathrm{C}$ atomic ratio, based on SEM-EDS analysis of materials resulting from interactions of minerals with pyrogenic carbon [12]. The known methods for the quantification of pyrogenic carbon $(\mathrm{PyC})$ in carbonaceous materials present the basic principle of PyC thermoxidation. the method named Molecular Marker [13] [14] [15] is included among the first published and involves several steps, such as: (a) thermoxidation after digestion with hot $\mathrm{HNO}_{3}$ and consequent formation of polycarboxylic benzene acids (BPCAs); elimination of interfering cations by means of highly acidified cation exchange resins; poster treatments with organic substances, aiming at obtaining trimethylsilyl derivatives, which will be stabilized for at least a week to prevent the samples from decomposing through contact with water and air; finally quantification by gas 
chromatography with flame ionization detector (FID) [13].

Among the other thermoxidation methods applied in the quantification of PyC and considered to be of high efficiency are: CTO-375, validated by Gustafsson et al. (1997) [16] and explained in detail by Elmquist et al., (2004) [17]; Hidropoly-method (Meredith, et al. 2012) [18].

Data on determination pyrogenic carbon concentrations, named stable carbon (CS), known as CTO-375, are still restricted in ABE samples, but obtained from carbonaceous materials from different sources [19] [20] and materials obtained by interactions of pyrogenic carbon with minerals of soils, applied as fertilizers but which can be harmful to soils and groundwater [16], due to the presence of polycyclic aromatic hydrocarbons (hpas), strongly adsorbed on biochars, thus requiring prior selection of suitable extractors that enable the quantification of hpas on biochars [21] [22] [23].

The present study assesses the affinity between available concentrations of phosphorus and micronutrients $(\mathrm{Cu}, \mathrm{Zn}$ and $\mathrm{Mn})$ in different sequential solid phases in $\mathrm{ABE}$ (exchangeable, linked to carbonates, $\mathrm{Fe}-\mathrm{Mn}$ and organic oxides) and their relationship with total and stable carbon, in order to add contributions to the understanding of the recalcitrance of organic matter from ABE site Ilha de Terra. The research is innovative, as it applied for the first time a dry method for the determination of nutrients, without the use of organic reagents, with a clean chemistry character in the ABE analyses.

\section{Materials and Methods}

\subsection{Study Area}

The study area is located approximately $400 \mathrm{~km}$ west of Belém, between the municipalities of Portel and Melgaço-Pará. The region is formed by the bay of Caxiuanã, where on its margins are concentrated several archaeological sites, such as the Manduquinha and Ilha de Terra sites [11] [12]. The geological profile of the area is represented by a lower kaolinitic zone, with a thickness of approximately $5 \mathrm{~m}$; intermediate ferruginous zone with a thickness of about $2.5 \mathrm{~m}$, covered by a layer of yellow Latosoil, thickness between 29 and $110 \mathrm{~cm}$; layer of $A B E$ in higher areas, with thickness between 7 to $29 \mathrm{~cm}$.

\subsection{Materials}

The samples selected in this study were three in the $A 1$ and $A 2$ horizons of $A B E$ plus the sample of the underlying Latosoil $\mathrm{AB}$ horizon (Ls- $\mathrm{AB}$ ) at points indicated on the sampling map, as illustrated in a previous study [12], making a total of seven samples (Table 1). All reagents used in this work were of analytical grade and had high levels of purity.

1) Chemical properties of $A B E$ and subjacent Latossoil

The main chemical properties inherent to soil fertility are determined and interpreted according to the analytical procedures described in Manuals of chemical analysis of soils [24], being thus determined: sum of the bases (SB), 
Table 1. Identification and discrimination of samples ABE from Ilha de Terra site.

\begin{tabular}{cc}
\hline Samples & Discrimination \\
\hline 1) ABEA1 & LT.60-150-220-A1 \\
2) ABEA1 & LT.60-280-340-A1 \\
3) ABEA1 & LT.60-360-440-A1 \\
5) ABEA2 & LT.60-150-220-A2 \\
6) ABEA2 & LT.60-280-340-A2 \\
7) Ls. AB & LT.60-360 - 440-A2 \\
\hline
\end{tabular}

represented by the sum of the concentrations of $\mathrm{Na}, \mathrm{K}, \mathrm{Ca}$ and $\mathrm{Mg}$; phosphorus concentration; active acidity $\left(\mathrm{pH}_{\mathrm{H}_{2} \mathrm{O}}\right)$, exchangeable acidity (exchangeable aluminum, represented as $\mathrm{Al}$ and potential, indicated as $\left(\mathrm{Al}+\mathrm{H}^{+}\right.$; effective CEC and total CEC, base saturation (\% V) and saturation of aluminum (\% $\mathrm{m})$.

The concentrations of phosphorus, $\mathrm{Na}$ and $\mathrm{K}$ are determined from extraction with Mehlich 1 solution ( $\mathrm{HCl} 0.05 \mathrm{~mol} \mathrm{~L}^{-1}+\mathrm{H}_{2} \mathrm{SO}_{4} 0.05 \mathrm{~mol} \mathrm{~L}^{-1}$ ) and those of $\mathrm{Ca}, \mathrm{Mg}$ and $\mathrm{Al}$ from extraction with $1 \mathrm{~mol} \mathrm{~L}^{-1} \mathrm{KCl}$ solution

Based on the data obtained for base saturation $(\% \mathrm{~V})$, it is possible to indicate whether the soils are eutrophic ( $\% \mathrm{~V}>50 \%$ ), meaning that more than $50 \%$ of the negative soil loads are occupied by bases. If $\mathrm{V}<50 \%$, soils are dystrophic, meaning that less than $50 \%$ of negative soil loads are occupied by bases. The aluminum saturation expresses the\% of CTC occupied by the exchangeable Al. Soils with values of $\% \mathrm{~m}>50 \%$ are considered to harmful to plants. The concentration of exchangeable $\mathrm{Al}$ tends to decrease with increasing soil $\mathrm{pH}$.

2) Sequential extraction procedure

In the sequential extraction of available nutrients, $\mathrm{P}, \mathrm{Cu}, \mathrm{Mn}$ and $\mathrm{Zn}$ in soils, the classic Tessier method, according to the steps summarized below [25] [26] [27].

1nd.stage: treatment of the sample with $\mathrm{MgCl}_{2}$ extracting solution; $\mathrm{pH}=7$, or sodium acetate solution, $\mathrm{pH}=8.2$, fraction corresponding to exchangeable $(\mathrm{K}$, $\mathrm{Ca}, \mathrm{Mg}$ ) occurs, the solid/liquid ratio $=8$. After stirring and centrifuging, the $\mathrm{F} 1$ extract is reserved for chemical analysis.

2nd stage: extraction of the fraction bound to carbonates, according to the procedures: to the R1 residue, the extraction solution formed by sodium acetate plus acetic acid in equal volumes and concentrations is added, resulting in a solution with $\mathrm{pH}=5$ with a solid/liquid ratio $=8$; obtaining after extraction residue 2 and extract 2.

3rd stage: extraction of the fraction bound to iron and manganese oxides, with solid/liquid ratio $=20$. To the $\mathrm{R} 2$ residue is added the sodium dithionite extracting solution of $\mathrm{Na}_{2} \mathrm{~S}_{2} \mathrm{O}_{4}$ plus sodium nitrate, second or hydroxylamine chloridate solution $\mathrm{OH}$. $\mathrm{HCl}$ in $25 \%$ acetic acid solution obtains residue $\mathrm{R} 3$ and extract 3. 
4th stage: extraction of the bound fraction in the organic matter, with sol$\mathrm{id} /$ liquid ratio $=16$. To the residue $\mathrm{R} 3$, diluted $\mathrm{HNO}_{3}$ solution is added; Concentrated $\mathrm{H}_{2} \mathrm{O}_{2}$; heating to about $85^{\circ} \mathrm{C}$; then cooling, adding ammonium acetate solution in $20 \% \mathrm{v} / \mathrm{v}$ nitric acid, resulting in residue $\mathrm{R} 4$ and extract 4 at the end.

5th stage- Residue 4 is treated with $\mathrm{HClO}_{4}$ : $\mathrm{HF}$ at a temperature below $300^{\circ} \mathrm{C}$ until close to dryness and the residue dissolved in dilute $\mathrm{HNO}_{3}$ solution.

3) Determination concentrations of nutrients

Phosphorus concentrations were measured by spectrophotometric method as heteopoly blue [24], $\mathrm{Na}, \mathrm{K}, \mathrm{Ca}, \mathrm{Mg}, \mathrm{Cu}, \mathrm{Zn}$, and $\mathrm{Mn}$ by MP-AES.

4) Determination concentrations of stable carbon from CTO-375 method

The determination of stable carbon concentrations from CTO-375, involves the following steps [16].

a) Determination of total organic carbon by combustion method (TOC.1: using sample without heat treatment);

b) In a muffle furnace $5 \mathrm{~g}$ of sample was heated in a porcelain vessel. The temperature controller allowed very accurate control of the temperature and prevented the temperature from exceeding $375^{\circ} \mathrm{C}$, the initial temperature increase corresponded to $10^{\circ} \mathrm{C}$ starting at room temperature until $350^{\circ} \mathrm{C}$ was reached, and was followed by an increase of $0.5^{\circ} \mathrm{C} \mathrm{min}^{-1}$ to $375^{\circ} \mathrm{C}$ in airflow 200 $\mathrm{mL} \min ^{-1}$ during $18 \mathrm{~h}$ the whole procedure to oxidize organic matter;

c) Treatment wich $\mathrm{HCl} 1 \mathrm{~mol} \mathrm{~L}^{-1}$ for the remotion of carbonate;

d) Determination TOC concentration by combustion, method, being the result corresponding to the CTO-375, named stable carbon.

5) Calculate the concentration of inorganic carbon

The concentration is obtained from the difference between the masses $\mathrm{m} 1$ and $\mathrm{m} 2$, indicated in steps 1 and 3.

6) Concentration semi-labile carbon

The concentration of semi-labile carbon can be estimated from data obtained during thermoxidation treatments, being then estimated in this study by the difference between calculating the concentration of inorganic carbon:

The concentration is obtained from the difference between the masses $\mathrm{m} 1$ and $\mathrm{m} 2$, indicated in steps 1 and 3.

7) Determination of the concentration of oxidizable organic carbon and soil organic matter (MOS)

The method applied is the Walkley-Black, which is the most cited and recognized for the determination of oxidizable organic carbon and MOS and consists of the oxidation of organic matter with an excess of strongly oxidizing solution and subsequent reaction of the excess oxidant with $\mathrm{Fe}^{2+}$ solution in acid medium. This method considers that only $77 \%$ of the soil organic matter (SOM) is oxidized and that SOM contains about $58 \%$ of $\mathrm{C}$. Therefore, to obtain the total organic carbon concentration (TOC), the organic carbon must be multiplied partial by the factor 1.2987 and to transform the TOC value obtained in soil organic matter (SM), another multiplication by factor 1.7241 (method 6) [24]. 


\section{Results and Discussion}

\section{Chemical Characteristics that Express Soil Fertility}

The samples of Tpas and oxisol analyzed show (Table 2): base saturation values $\mathrm{V}>50 \%$, indicating a high base occupation in the negative charges of these soils that fit as eutrophic; in the evaluation of the value obtained it was verified that the values are included among those considered as of average damage to the plants (Brazão, 2018) [28] [29].

In the evaluations of the data obtained in TPA in relation to those obtained in Latosol, it appears that they are compatible with those expected, thus indicating an increase in the values of effective and potential CTC, base saturation (\% V), oxidable carbon (Ox.C) and concentration of $\mathrm{P}_{2} \mathrm{O}_{5}$, thus reflecting improvement of conditions favorable to the stability of organic matter in Tpa of the Ilha de Terra site. The values of $\% \mathrm{~V}$ indicate that $\mathrm{ABE}$ and Latosoil from the Ilha de Terra site fit as eutrophic, as well as in other sites in the Caxiuanã region and in other places in the Brazilian Amazon [7].

1) Concentrations of different forms of carbon

The data of oxidable carbon concentrations from ABE samples in this study (Table 3), corresponding to about $88 \%$ of the TOC concentrations determined

Table 2. Concentrations of Ox.C (\%), $\mathrm{P}_{2} \mathrm{O}_{5}\left(\mathrm{mg} \cdot \mathrm{kg}^{-1}\right)$, sum of bases (SB), exchangeable $\mathrm{Al}$ (ex.Al), active acidity and potential $\left(\mathrm{pH}_{\mathrm{H}_{2} \mathrm{O}} ;\left(\mathrm{Al}+\mathrm{H}^{+}\right)\right)$, cec efetive and potential, base and $\mathrm{Al}$ saturation (\% $\mathrm{V}$ and $\mathrm{m})$.

\begin{tabular}{ccccccccccc}
\hline Samples & Ox.C & $\mathrm{P}_{2} \mathrm{O}_{5}$ & $\mathrm{SB}$ & ex.Al & $\mathrm{pH}_{\mathrm{H}_{2} \mathrm{O}}$ & Ac.pt & cec.pt & Cec.ef & $\mathrm{V}$ & $\mathrm{M}$ \\
\hline 1) ABEA1 & 3.35 & 211 & 25 & 2.57 & 4.31 & 9.70 & 36 & 28 & 69 & 9.20 \\
2) ABEA1 & 3.01 & 220 & 21 & 1.84 & 4.51 & 14.3 & 35 & 25 & 60 & 7.36 \\
3) ABEA1 & 3.65 & 240 & 21 & 2.47 & 4.31 & 13.80 & 35 & 26 & 60 & 9.50 \\
4) ABEA2 & 2.20 & 108 & 17 & 3.08 & 4.81 & 10.40 & 27 & 20 & 63 & 15.40 \\
5) ABEA2 & 2.11 & 105 & 20 & 2.57 & 4.51 & 13.60 & 34 & 22 & 59 & 11.70 \\
6) ABEA2 & 2.48 & 62 & 18 & 2.97 & 4.31 & 13.20 & 31 & 21 & 58 & 14.10 \\
7) Ls. AB & 0.89 & 60 & 16 & 0.68 & 5.18 & 14.30 & 30 & 17 & 53 & 4.00 \\
\hline
\end{tabular}

Table 3. Carbon concentrations (\%) in samples of ABE and Latosoil.

\begin{tabular}{rccccc}
\hline Samples & TOC & Stable & Semi-labile & Oxidable & Inorganic \\
\hline Tpa. 1-A1 & 3.55 & 0.52 & 3.03 & 3.48 & 0.14 \\
Tpa. 2-A1 & 3.54 & 0.25 & 2.29 & 2.90 & 0.03 \\
Tpa. 3-A1 & 3.94 & 0.31 & 3.63 & 3.7 & 0.01 \\
Tpa. 1-A2 & 2.36 & 0.22 & 2.14 & 2.3 & 0.11 \\
Tpa. 2-A2 & 2.63 & 0.88 & 1.75 & 2.20 & 0.38 \\
Tpa. 3-A2 & 2.71 & 0.37 & 2.34 & 2.30 & 0.18 \\
latosoilAB & 1.05 & 0.02 & 1.03 & 0.89 & $\mathrm{Nd}$ \\
\hline
\end{tabular}


by the dry combustion method, being the values compatible with that indicated in the evaluations of the differences between TOC and Ox.C in various types of carbonaceous materials [10], which resulted in the range of $78.4 \%$ to $89.3 \%$. The concentrations of oxidable carbon in the $\mathrm{ABE}$ samples of this study are included between the upper values of the intervals obtained for the ABE of the Manduquinha site (0.33 - 4.09) [11].

The concentrations of semi-labile carbon represent about $80 \%$ to $81 \%$ of TOC in the ABE samples in this study. The concentrations for this carbon fraction should be normal in $\mathrm{ABE}$, but much higher than in materials obtained from thermochemical interactions of soils with biomass, evaluated as fertilizers being obtained concentrations at the level of ng [22].

The concentrations of inorganic carbon are within the expected values, due to the very common presence of human bones observed during sampling steps.

In the evaluation of the stable carbon concentrations obtained in this study with those obtained in other carbonaceous materials from different source was found that they are included in the range of values obtained for samples and charcoal residues $(0.3 \%$ and $4.0 \%)$ and well below those obtained in: urban dust (4.4\% and $18.7 \%)$; wood charcoal (20.1\% and $53 \%)$; straw charcoal $(12.8 \%$ and 43.3\%) [20].

2) Concentrations of $\mathrm{P}_{2} \mathrm{O}_{5}, \mathrm{Cu}, \mathrm{Mn}, \mathrm{Zn}$ from sequential extraction

3) Phosphorus concentrations

Phosphorus concentrations in the exchangeable fraction (F1) in ABE are available as $\mathrm{HPO}_{4}^{2-}$, which is the predominant ion $\mathrm{pH}>5$, as those which $\mathrm{pH}_{\mathrm{H}_{2} \mathrm{O}}$ indicated for samples studied (Table 4) and infraction bound to carbonates (F2) at $\mathrm{pH}$ of the extractor equivalent to 5 , the predominant ionic form is $\mathrm{H}_{2} \mathrm{PO}_{4}^{-}$[30].

The exchangeable fraction and the carbonate bond are those available to plants and the phosphorus concentrations obtained in these fractions, expressed as $\mathrm{P}$ in $\mathrm{mg} \cdot \mathrm{L}^{-1}$ are included in the ranges: in $\mathrm{F} 1=0.33$ to $2.1 \mathrm{mg} \cdot \mathrm{L}^{-1}$ and in $\mathrm{F} 2=$ 1.33 to $4.64 \mathrm{mg} \cdot \mathrm{L}^{-1}$ and in these intervals the values are considered low for soils with a sandy texture, such as samples of its Tpa $\left(\mathrm{P}\right.$ in $\left.\mathrm{mg} \cdot \mathrm{L}^{-1}>9\right)$. In the Fe-Mn

Table 4. $\mathrm{P}_{2} \mathrm{O}_{5}$ concentrations in the exchangeable phases (P1), bound to carbonates (P2), Fe-Mn oxides (P3), organic (P4) and residual (P5) from ABE.

\begin{tabular}{ccccccc}
\hline & \multicolumn{6}{c}{ Concentrations of $\mathrm{P}_{2} \mathrm{O}_{5}\left(\mathrm{mg} \cdot \mathrm{kg}^{-1}\right)$} \\
\cline { 2 - 7 } Phases & \multicolumn{2}{c}{ Tpa. 1 } & \multicolumn{3}{c}{ Tpa. 2 } & \multicolumn{3}{c}{ Tpa. 3 } \\
\cline { 2 - 7 } & $\mathrm{A} 1$ & $\mathrm{~A} 2$ & $\mathrm{~A} 1$ & $\mathrm{~A} 2$ & $\mathrm{~A} 1$ & $\mathrm{~A} 2$ \\
\hline P1 & 4.90 & 1.40 & 4.81 & 1.11 & 0.76 & 1.16 \\
P2 & 10.80 & 3.11 & 5.25 & 3.30 & 4.47 & 3.34 \\
P3 & 112.00 & 53.60 & 33.80 & 27.00 & 37.00 & 19.00 \\
P4 & 716.00 & 496.00 & 508.00 & 347.00 & 200.00 & 188.00 \\
P5 & 215.00 & 175.00 & 260.00 & 200.00 & 158.00 & 116.00 \\
\hline
\end{tabular}


oxide phases, they are compatible with those of other $\mathrm{ABE}$ occurrences with a sandy-clay texture [6]. In the organic phase, the high concentrations of phosphorus obtained are justified by the presence of residues of human or animal bones observed in the sampling area.

4) Copper concentration

The copper concentrations obtained in phases P1 and P2 fall into the high level for plants $\left(>1.8 \mathrm{mg} \cdot \mathrm{L}^{-1}\right)$ [24]. The ionic form of copper in this phase is $\mathrm{Cu}^{2+}$ that is predominant between $\mathrm{pH}=3$ to 5 [28], tipic in $\mathrm{ABE}$, according to values indicated for samples in this study (Table 5).

In the evaluation of the concentrations in phases $\mathrm{f} 1$ to $\mathrm{f} 3$ with those indicated in $\mathrm{ABE}$ other occurrences it was verified that the values are higher than the obtained in the of the municipality of Juruti (0.01 to $\left.0.45 \mathrm{mg} \cdot \mathrm{kg}^{-1}\right)$ [29] and in the Laranjal community, (2, 3 and $\left.6 \mathrm{mg} \cdot \mathrm{kg}^{-1}\right)$ [6]; included in the range obtained in $\mathrm{ABE}$ of the Manduquinha site $\left(\mathrm{C}=10\right.$ to $\left.14 \mathrm{mg} \cdot \mathrm{kg}^{-1}\right)$ [11]; interval much lower than that of Tpas in the district of Iranduba, close to Manaus (90 to $104 \mathrm{mg} \cdot \mathrm{kg}^{-1}$ ) [6].

5) Concentrations of manganese

The concentrations of manganese (Table 6) obtained in the exchangeable fraction fall within the low level for plants $\left(<5 \mathrm{mg} \cdot \mathrm{L}^{-1}\right)$ [30] [31]. In fractions $\mathrm{F} 2$,

Table 5. Copper concentration in the exchangeable fractions (P1), bound to carbonates (P2), Fe-Mn oxides (P3), organic (P4) and residual (P5) phases from ABE.

\begin{tabular}{ccccccc}
\hline \multirow{2}{*}{ Phases } & \multicolumn{6}{c}{ Copper concentration $\left(\mathrm{mg} \cdot \mathrm{kg}^{-1}\right)$} \\
\cline { 2 - 7 } & \multicolumn{2}{c}{ Tpa. 1 } & \multicolumn{2}{c}{ Tpa. 2 } & \multicolumn{2}{c}{ Tpa. 3 } \\
\cline { 2 - 7 } & A1 & A2 & A1 & A2 & A1 \\
\hline P1 & 6.58 & 5.48 & 5.84 & 7.06 & 4.84 & 13.30 \\
P2 & 4.53 & 5.85 & 4.25 & 8.11 & 10.90 & 8.20 \\
P3 & 7.45 & 6.21 & 6.11 & 7.96 & 4.70 & 8.20 \\
P4 & 30.42 & 10.00 & 18.80 & 9.61 & 11.50 & 11.80 \\
P5 & 11.51 & 24.00 & 9.94 & 23.30 & 10.00 & 20.80 \\
\hline
\end{tabular}

Table 6. Concentrations of manganese in the exchangeable fractions (P1), bound to carbonates (P2), Fe-Mn oxides (P3), organic (P4) and residual (P5) phases from ABE.

\begin{tabular}{ccccccc}
\hline & \multicolumn{5}{c}{ Concentrations of manganese $\left(\mathrm{mg} \cdot \mathrm{kg}^{-1}\right)$} \\
\cline { 2 - 7 } Phases & \multicolumn{2}{c}{ Tpa. 1 } & \multicolumn{3}{c}{ Tpa. 2 } \\
\cline { 2 - 7 } & A1 & A2 & A1 & A2 & A1 & A2 \\
\hline P1 & 1.68 & 1.10 & 1.23 & 0.80 & 0.80 & 0.70 \\
P2 & 3.40 & 3.60 & 1.70 & 1.30 & 7.80 & 1.00 \\
P3 & 7.80 & 1.60 & 4.00 & 5.00 & 2.30 & 14.00 \\
P4 & 9.80 & 0.70 & 2.00 & 0.70 & 2.20 & 0.70 \\
P5 & 53.00 & 97.00 & 55.00 & 82.00 & 36.00 & 44.00 \\
\hline
\end{tabular}


manganese occurs not available in carbonatoapatite residues from human or animal bones, common in $\mathrm{ABE}$ and observed in a previous study [11] [12]. In the oxide fraction of $\mathrm{Fe}-\mathrm{Mn}$, manganese occurs in residues of goethite and hematite, resistant to the interaction process with pyrogenic carbon, according to observations by SEM/EDS made in a previous study [32].

In the F4 fraction, manganese has the lowest concentrations, and this aspect is justified because it was not made available under the conditions of the applied extraction, thus being stored in organic aggregates from mineral interactions with pyrogenic carbon [33].

In the assessment of manganese concentrations in Tpa samples in this study with those from other locations, it was found that: in phases F1 to F3, they are lower than the values presented for Tpas in the municipality of Juruti (6.15 to $48.5 \mathrm{mg} \cdot \mathrm{kg}^{-1}$ ) [32] which were obtained by the same method.

6) Zinc concentrations

The average zinc concentration in the exchangeable fraction (Table 7) is high for plants (>2.2 mg. $\mathrm{L}^{-1}$ ) [24]. In fractions F2, zinc occurs not available in carbonateapatite residues from human or animal bones, common in $\mathrm{ABE}$ and observed in a previous study. In the oxide fraction of $\mathrm{Fe}-\mathrm{Mn}$, manganese occurs in residues of kaolinite, resistant to the interaction process with pyrogenic carbon, according to observations by SEM/EDS made in a previous study [12].

In the evaluation of zinc concentrations in Tpa samples in this study with those from other locations it was found that: in phases P1 to P3 the concentrations are lower than those indicated for Tpa in the municipality of Juruti (2.38 to $12.61 \mathrm{mg} \cdot \mathrm{kg}^{-1}$ ) [29] and in $\mathrm{ABE}$ of districts near to Manaus, such as Iranduba (>150 mg. $\mathrm{kg}^{-1}$ ) [1] and Laranjal Tpa with clay texture (275 to $325 \mathrm{mg} \cdot \mathrm{kg}^{-1}$ ) [6].

Variations in the concentrations of $\mathrm{P}_{2} \mathrm{O}_{5}, \mathrm{Cu}, \mathrm{Mn}, \mathrm{Zn}$ in phases $\mathrm{F} 1$ to $\mathrm{F} 4$ are in relation to the concentrations of total and stable organic carbon.

In the exchangeable phase (Figure 1), it is observed that the concentrations of copper, manganese and zinc are more affected by the increase in the concentrations of TOC than those of phosphorus. This aspect is not observed for the distribution of nutrients in relation to the stable carbon.

Table 7. Concentrations of zinc in the exchangeable fractions (P1), bound to carbonates (P2), Fe-Mn oxides (P3), organic (P4) and residual (P5) phases from ABE.

\begin{tabular}{ccccccc}
\hline & \multicolumn{5}{c}{ Concentrations of zinc $\left(\mathrm{mg} \cdot \mathrm{kg}^{-1}\right)$} \\
\cline { 2 - 7 } Phases & \multicolumn{2}{c}{ Tpa. 1 } & \multicolumn{3}{c}{ Tpa. 2 } & \multicolumn{3}{c}{ Tpa. 3 } \\
\cline { 2 - 7 } & A1 & A2 & A1 & A2 & A1 & A2 \\
\hline P1 & 1.72 & 8.20 & 3.52 & 8.30 & 5.60 & 10.40 \\
P2 & 1.30 & 9.10 & 5.20 & 8.40 & 6.80 & 11.30 \\
P3 & 3.96 & 12.40 & 6.50 & 12.70 & 10.40 & 14.30 \\
P4 & 8.80 & 12.00 & 10.10 & 11.50 & 12.00 & 14.00 \\
P5 & 18.00 & 31.50 & 15.00 & 37.00 & 11.00 & 34.00 \\
\hline
\end{tabular}


In the phase bound to carbonates (Figure 2) the distribution of phosphorus concentrations in relation to carbon concentrations is more homogeneous and without prominence in samples with lower concentrations of TOC and stable carbon, while the distribution of micronutrients has the opposite aspect [34]. Phosphorus in this fraction should be gradually made available from relics of human and animal bones, just as it occurs in other archaeological sites in various regions of the Brazilian Amazon, such as in places close to Manaus [6], in the district of Iranduba, Manicoré and in the other sites of the Caxiuanã region [11].

In the exchangeable fraction (Figure 3), it is observed that the concentrations of nutrients bound to phase Fe-Mn oxides (F3) stand out the increase in the concentrations of phosphorus with total organic carbon and stable carbon. This characteristic of phosphorus distribution in relation to carbon concentrations is even more evident in the organic phase (F4), where the concentrations of micronutrients emit aspect of storage in organic aggregates (Figure 4).

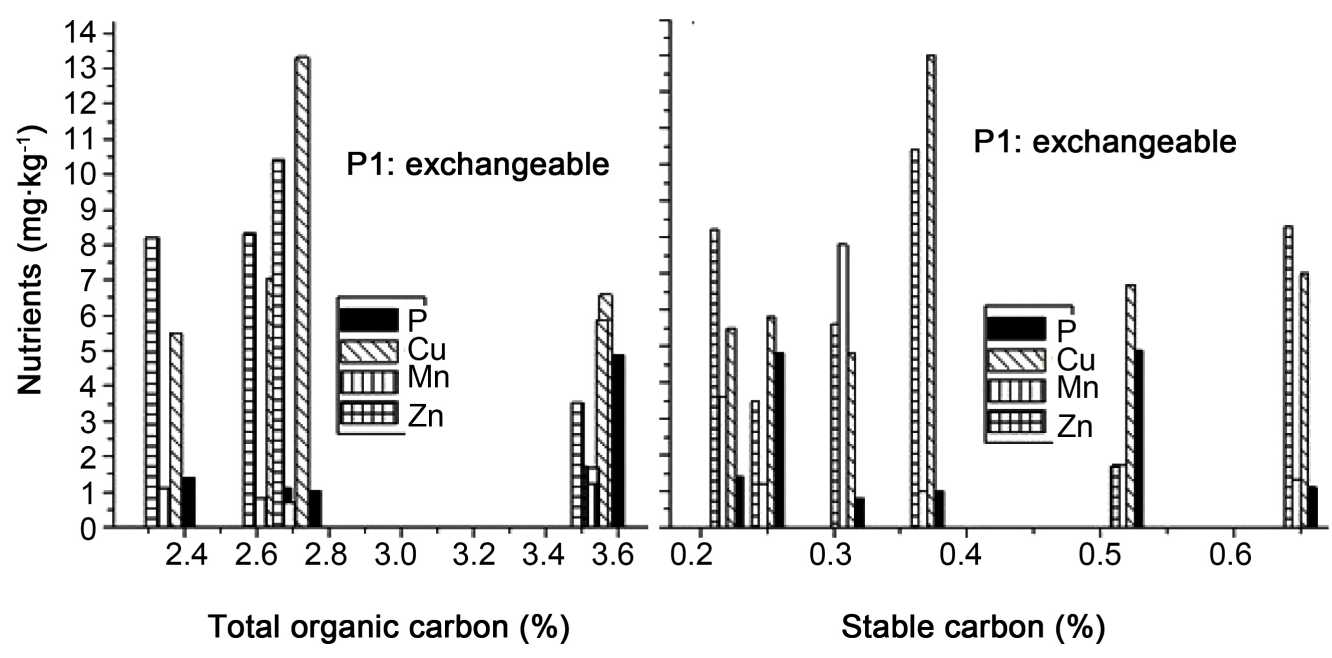

Figure 1. Concentrations of $\mathrm{P}_{2} \mathrm{O}_{5}, \mathrm{Cu}, \mathrm{Mn}, \mathrm{Zn}\left(\mathrm{mg} \cdot \mathrm{kg}^{-1}\right)$ in the exchangeable phase in relation to the concentrations of TOC and stable carbon.

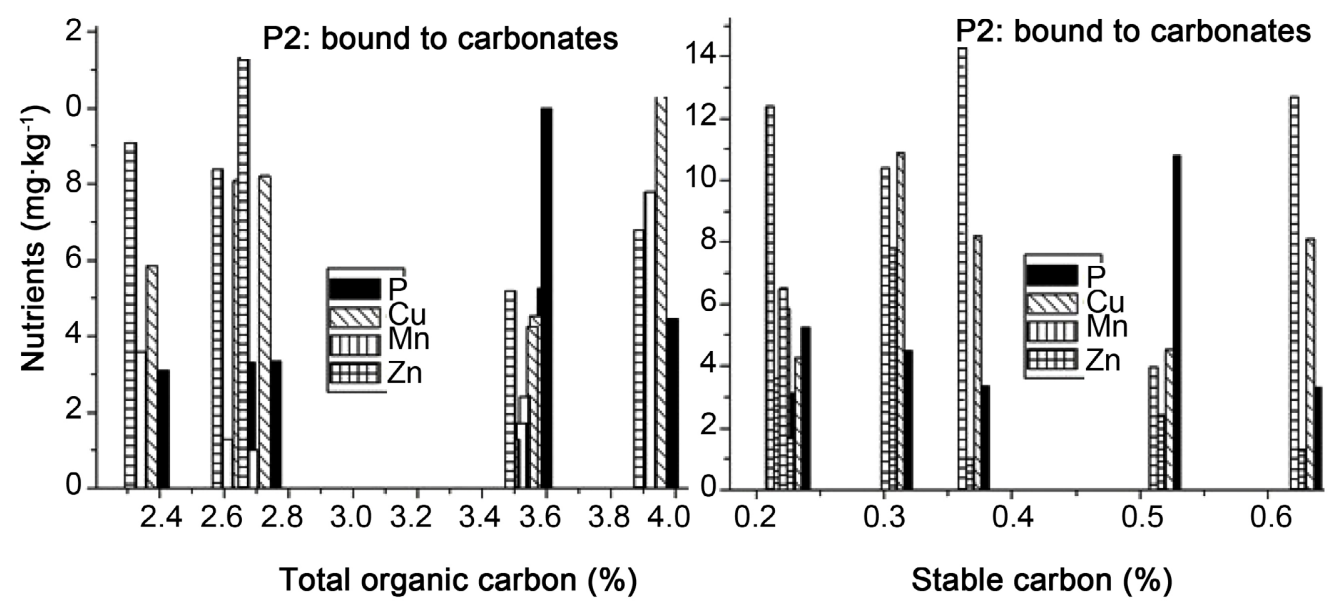

Figure 2. Concentrations of $\mathrm{P}_{2} \mathrm{O}_{5}, \mathrm{Cu}, \mathrm{Mn}, \mathrm{Zn}\left(\mathrm{mg} \cdot \mathrm{kg}^{-1}\right)$ in the bound to carbonates phase in relation to the concentrations of TOC and stable carbon. 


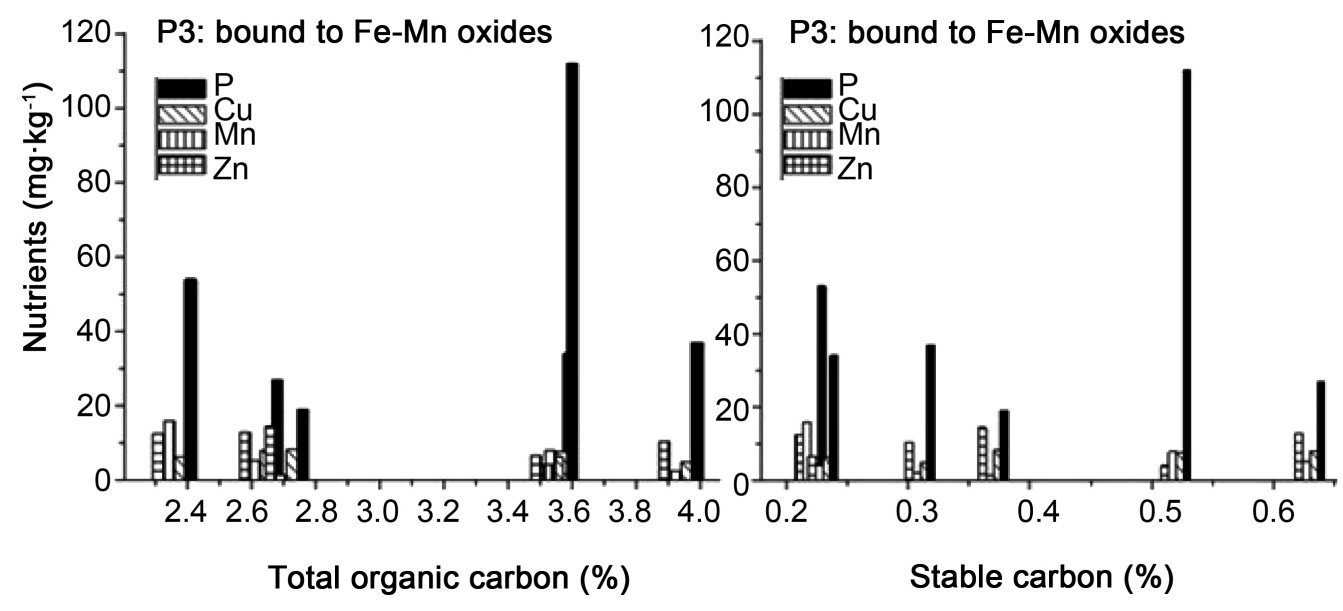

Figure 3. Concentrations of $\mathrm{P}_{2} \mathrm{O}_{5}, \mathrm{Cu}, \mathrm{Mn}, \mathrm{Zn}\left(\mathrm{mg} \cdot \mathrm{kg}^{-1}\right)$ phase bound to Fe-Mn oxides.

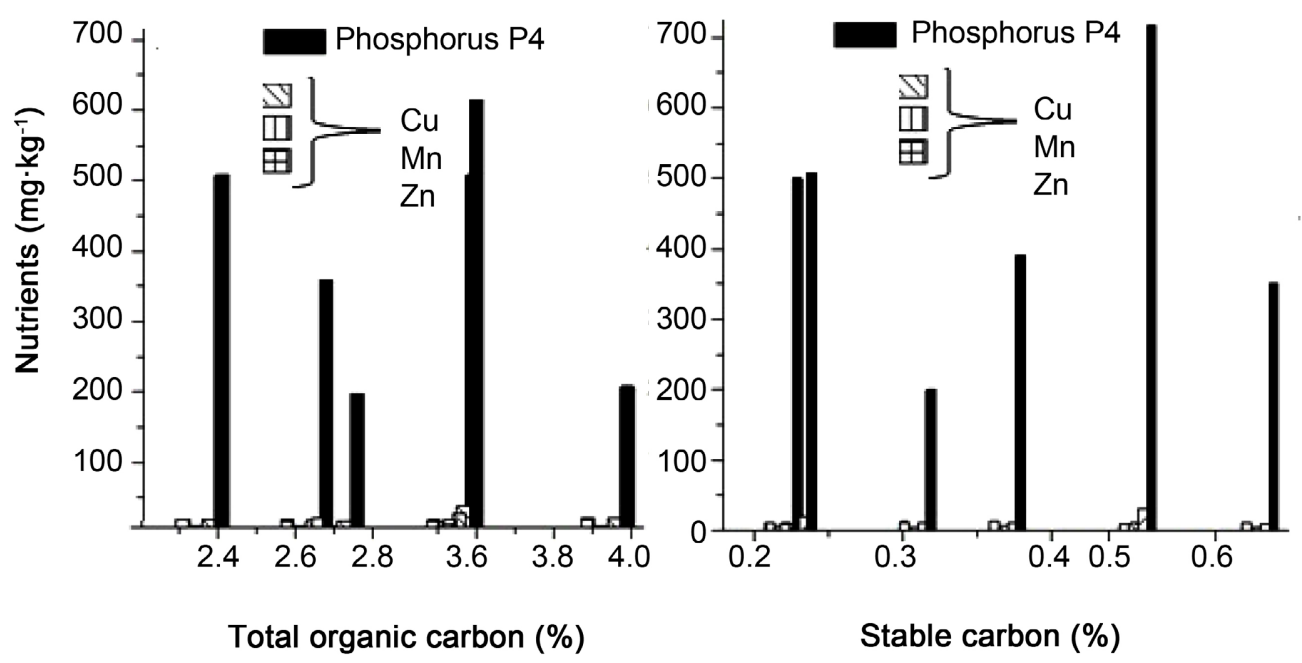

Figure 4. Concentrations of $\mathrm{P}_{2} \mathrm{O}_{5}, \mathrm{Cu}, \mathrm{Mn}, \mathrm{Zn}\left(\mathrm{mg} \cdot \mathrm{kg}^{-1}\right)$ bound to organic phase.

\section{Conclusions}

The study involving the determination of concentrations of available nutrients of phosphorus, copper, manganese and zinc available in ABE from different sequential solid phases P1 to P5 (associated with exchangeable, carbonates, Fe-Mn oxides, organic and residual), total and stable Carbon and other chemical properties in ABE from the archaeological site Ilha de Terra. The following conclusions were obtained:

1) The attributes obtained for the control of nutrients in ABE and Latosoil indicated: values for the base saturation index $\mathrm{V}>50 \%$, which fit as eutrophic.

2) In the evaluation of available concentrations of nutrients in relation to the stable carbon and TOC concentrations, it was concluded that the Fe-Mn oxide and organic phases represent the nutrient stocks phases in ABE of the Ilha de Terra site.

3) The high concentrations of phosphorus obtained are justified by the presence of residues of human or animal bones observed in the sampling area. 
4) The evaluated nutrients, with the exception of phosphorus, indicate an aspect of retention in the organic phase.

5) The concentrations of inorganic carbon in $\mathrm{ABE}$ of the studied site are higher than those indicated in other occurrences in the central Amazon. This aspect is justified due to its biogenic origin.

\section{Conflicts of Interest}

The authors declare no conflicts of interest regarding the publication of this paper.

\section{References}

[1] Novotny, E.H., Hayes, M.H.B. and Madari, B.E.J. (2009) Lessons from the Terra Preta de Índios of the Amazon Region for the Utilisation of Charcoal for Soil Amendment. Journal of the Brazilian Chemical Society, 20, 1003-1010. https://doi.org/10.1590/S0103-50532009000600002

[2] Costa, M. and Kern, D.C. (2013) Analysis of the Spatial Distribution of Geochemical Signatures for the Identification of Prehistoric Settlement Patterns in ADE and TMA Sites in the Lower Amazon Basin. Journal of Archaeological Science, 40, 2771-2782. https://doi.org/10.1016/j.jas.2012.12.027

[3] Petter, F.A. and Madari, B.E.R. (2012) Biochar: Agronomic and Environmental Potential in Brazilian Savannah Soils. Revista Brasileira de Engenharia Agricola e Ambiental, 16, 761-768. https://doi.org/10.1590/S1415-43662012000700009

[4] Guggenberger, G. and Zech, W. (2000) Black Carbon in Density Fractions of Anthropogenic Soils of the Brazilian Amazon Region. Organic Geochemistry, 31, 669-678. https://doi.org/10.1016/S0146-6380(00)00044-9

[5] Husein, H.H., Mousa, M., Sahwan, W., Bäumler, R. and Lucke, B. (2019) Spatial Distribution of Soil Organic Matter and Soil Organic Carbon Stocks in Semi-Arid Area of Northeastern Syria. Natural Resources, 10, 415-432. https://doi.org/10.4236/nr.2019.1012028

[6] Glaser, B. and Birk, J.J. (2012) State of the Scientific Knowledge on Properties and Genesis of Anthropogenic Dark Earths in Central Amazonia (terra preta de Indio). Geochimica et Cosmochimica Acta, 82, 39-51. https://doi.org/10.1016/j.gca.2010.11.029

[7] Lima, H.N., Schaefer, C.E.R., Mello, J.W.V., Gilkes, R.J. and Ker, J.C. (2002) Pedogenesis and Pre-Colombian Land Use of "Terra Preta Anthrosols" ("Indian Black Earth") of Western Amazonia. Geoderma, 110, 1-17. https://doi.org/10.1016/S0016-7061(02)00141-6

[8] Cunha, T.J.F., Madari, B.E., Canellas, L.P., Ribeiro, L.P., Benites, V.M. and Santos, G.A. (2009) Soil Organic Matter and Fertility of Anthropogenic Dark Earths (Terra Preta de Índio) in the Brazilian Amazon Basin. Revista Brasileira de Ciência do Solo, 35, 85-93. https://doi.org/10.1590/S0100-06832009000100009

[9] Souza, W., Lima, H., Schafer, C., Teixeira, W.G., Pulinki, K. and Correa, G.R. (2009) Phosphorous Forms in Cultivated Indian Black Earth (Anthrosols) of Varying Texture in the Brazilian Amazon. Revista Brasileira de Ciência do Solo, 33, 1347-1355. https://doi.org/10.1590/S0100-06832009000500027

[10] Sanchez-Monedero, M.A., Roino, A., Martinez-Pardo, C., Cegarra, J. and Parede, C. (1996) A Microanalysis Method for Determining Total Organic Carbon in Extracts 
of Humic Substances. Relationships between Total Organic Carbon and Oxidable Carbono. Bioresource Technology, 57, 291-295. https://doi.org/10.1016/S0960-8524(96)00078-8

[11] Costa, M.L. and Kern, D.C. (1999) Geochemical Signatures of Tropical Soils with Archaeological Black Earth in the Amazon, Brazil. Journal of Geochemical Exploration, 66, 369-385. https://doi.org/10.1016/S0375-6742(99)00038-2

[12] Lemos, V.P., et al. (2011) Nutrients in Amazonian Black Earth from Caxiuanã Region. Journal of the Brazilian Chemical Society, 22, 772-779. https://doi.org/10.1590/S0103-50532011000400022

[13] Glaser, B., Haumaier, L., Guggenberger, G. and Zech, W. (1998) Black Carbon in Soils: The Use of Benzenecarboxylic Acids as Specific Markers. Organic Geochemistry, 29, 811-819. https://doi.org/10.1016/S0146-6380(98)00194-6

[14] Brodowski, S., Rodionov, A., Haumaier, L., Glaser, B. and Amelung, W. (2005) Revised Black Carbon Assessment Using Benzene Polycarboxylic Acids. Organic Geochemistry, 36, 1299-1310. https://doi.org/10.1016/j.orggeochem.2005.03.011

[15] Brodowski, S., Amelung, W., Haumaier, L. and Zech, W. (2007) Black Carbon Contribution to Stable Humus in German Arable Soils. Geoderma, 139, 220-228. https://doi.org/10.1016/j.geoderma.2007.02.004

[16] Gustafsson, Ö., Bucheli, T.D., Kukulska, Z. andersson, M., Largeau, C., Rouzaud, J.N., Reddy, C.M. and Eglington, T.I. (2001) Evaluation of a Protocol for the Quantification of Black Carbon in Sediments. Global Biogeochemical Cycles, 15, 881-890. https://doi.org/10.1029/2000GB001380

[17] Elmquist, M., Gustafsson, Ö. and Andersson, P. (2004) Characterization of Carbonaceous Combustion Residues. I. Morphological, Elemental and Spectroscopic Features. Limnology and Oceanography, 2, 417-427.

[18] Meredith, W., et al. (2012) Assessment of Hydropyrolysis as a Method for the Quantification of Black Carbon Using Standard Reference Materials. Geochimica et Cosmochimica Acta, 97, 131-147. https://doi.org/10.1016/j.gca.2012.08.037

[19] Hammes, K., et al. (2007) Comparison of Quantification Methods to Measure Fire-Derived (Black/Elemental) Carbon in Soils and Sediments Using Reference Materials from Soil, Water, Sediment and the Atmosphere. Global Biogeochemical Cycles, 21, GB3016. https://doi.org/10.1029/2006GB002914

[20] Fernandes, M.B., Skjemstad, J.O., Johnson, B.B., Wells, J.D. and Brooks, P. (2003) Characterization of Carbonaceous Combustion Residues. I. Morphological, Elemental and Spectroscopic Features. Chemosphere, 51, 785-795. https://doi.org/10.1016/S0045-6535(03)00098-5

[21] Anika, C., Abdul, M., Zahara, I. and Pauzi, M. (2015) The Impact of Biochars on Sorption and Biodegradation of Polycyclic Aromatic hydrocarbons in Soils-A Review. Environmental Science and Pollution Research, 22, 3314-3341. https://doi.org/10.1007/s11356-014-3719-5

[22] Rombolá, A.G., et al. (2015) Fate of Soil Organic Carbon and Polycyclic Aromatic Hydrocarbons in a Vineyard Soil Treated with Biochar. Environmental Science Technology, 49, 11037-11044. https://doi.org/10.1021/acs.est.5b02562

[23] Caruso, M.S.F. and Alaburda, J. (2008) Hidrocarbonetos policíclicos aromáticosBenzo(a)pireno: Uma revisão. Revista do Instituto Adolfo Lutz, 67, 27.

[24] USDA (2004) Soil Survey Investigations Report, 42, 700 p.

[25] Carminati-Lima, M., Giaconelli, M.B., Stupp, V. and Roberge, F.D. (2001) Especiação de cobre e chumbo em sedimento do Rio Tubarão (SC) pelo método Tessier. Química 
Nova, 24, 734-742. https://doi.org/10.1590/S0100-40422001000600005

[26] Tessier, P.G.C. and Campbell, M.B. (1979) Sequential Extraction Procedure for the Speciation of Particulate Trace Metals. Analytical Chemistry, 51, 844-851. https://doi.org/10.1021/ac50043a017

[27] Lã, U.R., Barra, C.M., Brasil, N.M., Mazur, N. and Veloso, A.C.X. (2003) Avaliação dos métodos de extração sequencial de Tessier, Keller e Miller na determinação de ferro nativo em três tipos de solos: Orgânico, brunizem e latossolo. Química Nova, 26, 323. https://doi.org/10.1590/S0100-40422003000300007

[28] Embrapa (1997) Manual de métodos de análise de solos. 2nd Edition, Centro Nacional de pesquisa de solos, Rio de Janeiro, 212 p.

[29] Brazão, S.S. (2018) Análise de solo para Ciências Agrárias. 2nd Edition, Edufra, Belém, 172 p.

[30] Butler, J.N. (1998) Ionic Equilibrium. 3rd Edition, John Wiley \& Sons Inc., Hoboken.

[31] Ikhsan, J., Wells, J.D., Bruce, B. and Johnson, B. (2004) The Effect of Aspartic Acid on the Binding of Transition Metals to Kaolinite. Journal of Colloid Interface Science, 273, 6-13. https://doi.org/10.1016/j.jcis.2004.01.060

[32] Mescouto, C.S.T., Lemos, V.P., Dantas Filho, H.A., Costa, M.L., Kern, D.C. and Fernandes, K.G. (2011) Distribution and Availability of Copper, Iron, Manganese and Zinc in the Archaeological Black Earth Profile from the Amazon Region. Journal of the Brazilian Chemical Society, 22, 1484-1492. https://doi.org/10.1590/S0103-50532011000800012

[33] Moraes, M.C., Lemos, V.P., Moraes, D. and Lamarão, C.N. (2015) Characterization and Distribution of Pyrogenic Carbon in a Fraction of Archaeological Black Earth from Caxiuanã. Journal of the Brazilian Chemical Society (Impresso), 26, 1-10. https://doi.org/10.5935/0103-5053.20150140

[34] Brodowski, S., John, B., Flessa, H. and Amelung, W. (2006) Aggregate-Occluded Black Carbon in Soils. European Journal of Soil Science, 57, 539-546. https://doi.org/10.1111/j.1365-2389.2006.00807.x 